The occurrence of a mass hysterical reaction shows not that the population is psychologically abnormal but merely that it is socially segregated and consists predominantly of young females.

Our reassessment has been possible only because of the generous help we have received from the medical, administrative, and nursing staff of the Royal Free Group of Hospitals. We would like to place on record our appreciation of this co-operation, which has been truly unstinting. Our views are, of course, entirely our own.

The electromyographic study was carried out at the Department of Electromyography at the Middlesex Hospital by kind permission of Dr. Pamela Fullerton. The expertize needed to make the recordings was supplied by Dr. Ian Wilkinson.

\section{REFERENCES}

Crowley, N., Nelson, M., and Stovin, S. (1957). Fournal of Hygiene, 55, 102. Geffen, D., and Tracy, S. M. (1957). British Medical fournal, 2, 904.

Huxley, Aldous (1952). The Devils of Loudun. London, Chatto and Windus. Janet, P. (1907). The Major Symptoms of Hysteria. New York, MacMillan. Kerckhoff, A. C., and Back, K. W. (1968). The fune Bug. New York, Appleton-Century-Crofts

Lancet, 1956, 1, 789 .

McEvedy, C. P., Griffith, A., and Hall, T. (1966). British Medical fournal, 2, 1300 .

Medical Staff of the Royal Free Hospital (1957). British Medical fournal, 2, 895.

Moss, P. D., and McEvedy, C. P. (1966). British Medical fournal, 2, 1295.

Richardson, A. T. (1956). Annals of Physical Medicine, 3, 81.

Schuler, E. A., and Parenton, V. J. (1943). Fournal of Social Psychology, 17, 221

Tan, E. S. (1963-4). Medical fournal of Malaya, 18, 72.

\title{
Concept of Benign Myalgic Encephalomyelitis
}

\author{
COLIN P. MCEVEDY,* B.M., B.CH., ACAD.D.P.M. ; A. W. BEARD, † B.M., M.R.C.P., D.P.M.
}

\begin{abstract}
Cummary: The reports of the 15 recorded outbreaks of $\checkmark$ benign myalgic encephalomyelitis have been reviewed and in one instance the original clinical data studied. We believe that a lot of these epidemics were psychosocial phenomena caused by one of two mechanisms, either mass hysteria on the part of the patients or altered medical perception of the community. We suggest that the name "myalgia nervosa" should be used for any future cases of functional disorder which present the same clinical picture.
\end{abstract}

Acheson (1959), in a review article on benign myalgic encephalomyelitis, enumerated 14 epidemics that he considered belonged in this category. A fifteenth has been reported since (Daikos et al., 1959). The term "benign myalgic encephalomyelitis" was proposed in 1956 (Lancet, 1956), so the dozen outbreaks before this date have received the label retrospectively. The outbreaks, however, have so many features in common that the case for regarding at least the epidemic form of the illness as a unitary phenomenon is a very fair one.

In the preceding paper (McEvedy and Beard, 1970) we have presented the evidence for regarding one of the most striking epidemics in the series-the Royal Free Hospital outbreak of 1955-as an hysterical phenomenon. Can this formulation be applied to any or all of the other 14? After looking at the published reports on these epidemics (which we review below with our comments), and in one instance studying the original clinical data, our conclusion is that two mechanisms are at work, both psychosocial. We believe that between them they account for the phenomenon of benign myalgic encephalomyelitis.

\section{Hospital Outbreaks}

Of the 15 recorded outbreaks of benign myalgic encephalomyelitis eight have occurred among hospital nurses. The leading points about these eight are set out in Table I. We will look at two of them in some detail-the Los Angeles epidemic of 1934, because an excellent report on it has been published by the United States Public Health Service (Gil-

\footnotetext{
* Senior Registrar, Department of Psychological Medicine, the Middlesex Hospital, London W.1.

+Consultant Physician, Department of Psychological Medicine, the Middlesex Hospital, London W.1.
}

liam, 1938), and the Middlesex epidemic of 1952, because this is our hospital and we have had access to the clinical notes made at the time.

\section{Los Angeles Outbreak of 1934}

As shown in Table I, the Los Angeles outbreak occurred at a time when a poliomyelitis epidemic was under way in that area. The influx of poliomyelitis cases led to the opening of five emergency wards at the Los Angeles County Hospital during May 1934. A further 10 were opened in June; these were largely filled with suspected cases that had occurred among the younger members of the nursing staff of the hospital. The attack rate among the nurses was extraordinarily high $(12 \%$ as compared with $0.073 \%$ for the population of Los Angeles City and County). Moreover, it soon became apparent that the illness that had broken out among the nurses was not poliomyelitis. Whereas the cases admitted from outside had the clinical, laboratory, and necropsy findings characteristic of poliomyelitis, the nurses had: (1) temperatures fluctuating between 97 and $98^{\circ} \mathrm{F}$. ( 36.2 and $36.7^{\circ} \mathrm{C}$.); (2) more sensory than motor disturbance, with paraesthesiae, muscle tenderness, and general hyperaesthesia prominent; (3) muscular weakness only rarely associated with atrophy; (4) an unusually high frequency of "insomnia, emotional upsets, other disturbances of the sensorium, joint changes, trophic changes, oedema, cystitis, and menstrual disturbances"; (5) a normal cerebrospinal fluid; (6) a clinical course marked by relapses that were often as severe as the original illness; and (7) no mortality. This is the clinical picture that has since been termed benign myalgic encephalomyelitis.

One point of interest is the immunity of a second hospital that lay within the same grounds as the County Hospital. The staff of this institution (the County Osteopathic Hospital) had a very different age and sex distribution from the County Hospital proper. At the Osteopathic Hospital $44 \%$ of the staff was male (as compared with $27 \%$ at the County Hospital); of the females only two out of five were under 30 years old (as compared with three out of five at the County Hospital). By no means all the local institutions achieved this immunity. Leake et al. (1934) mentioned "a sharp focus in May in the Ruth Protective Home, an institution for infants, children, and young women, located about 3 miles' east of the city limits." Eleven out of about 100 inmates required admission. 
The Ruth Protective Home is just the sort of institution classically liable to mass hysteria. Conversely, in an hysterical outbreak one would expect the Osteopathic Hospital to be resistant, for three-quarters of its staff were either male or over 30 years old. We believe these epidemiological peculiarities-the predilection for young women and for institutions containing an undue proportion of them-provide gocd positive evidence for mass hysteria as an explanation of the illness.

The clinical data reported are compatible with a functional diagnosis. Points 1,5 , and 7 in the already quoted summary of symptoms are hardly evidence for organicity, and points 2 and 3 are more suggestive of functional than organic neurological disability.

Gilliam (1938) believed that he was dealing with a viral illness, but he does mention (in the last paragraph of his 69-page report) that "certain observers were of the privately expressed opinion that hysteria played a large role in this outbreak." This represents our view exactly. For though we think it of major importance we do not believe that mass hysteria was the sole factor at work. The possible supplementary mechanism is discussed after consideration of the next epidemic in the series.

\section{Middlesex Outbreak of 1952}

This outbreak involved 14 nurses over a 10 -week period. Case 1 reported ill on 7 July with headache, malaise, sore throat, and pains in the knees. $\neq \mathrm{Her}$ temperature was $103.4^{\circ} \mathrm{F} .\left(39.7^{\circ} \mathrm{C}\right.$.) and her tonsils were considerably inflamed. She was diagnosed as a case of tonsillitis and admitted to Princess Alice Ward. Penicillin was given for the next three days, her temperature fell to normal, and on 11 July she was noted to be quite well and fit for discharge the next day. (It is worth interpolating here that the patient had an exactly similar illness in 1957, when she was again diagnosed as having tonsillitis. On that occasion she was discharged after four days as an inpatient.)

¥ The numbering of the cases is that used by Acheson (1954).

TABLE I.-Eight Epidemics in Hospitals

\begin{tabular}{|c|c|c|c|c|c|c|c|c|c|c|c|c|c|c|}
\hline \multirow{3}{*}{ Year } & \multirow{3}{*}{ Hospital } & \multirow{3}{*}{$\begin{array}{l}\text { Initial } \\
\text { Diagnosis }\end{array}$} & & & & \multirow{3}{*}{$\begin{array}{l}\text { Female } \\
\text { Cases } \\
\text { as \% } \\
\text { of } \\
\text { total }\end{array}$} & \multirow{3}{*}{$\begin{array}{l}\text { No. of } \\
\text { Cases } \\
\text { Among } \\
\text { Nurses }\end{array}$} & \multirow{3}{*}{$\begin{array}{l}\text { Cases } \\
\text { among } \\
\text { nurses as } \\
o \% \text { of No. } \\
\text { of female } \\
\text { cases }\end{array}$} & \multicolumn{3}{|c|}{ Attack Rates } & \multirow{3}{*}{ Mortality } & \multirow{3}{*}{$\begin{array}{l}\text { Cerebro- } \\
\text { spinal fluid; } \\
\text { results of } \\
\text { lumbar } \\
\text { puncture }\end{array}$} & \multirow{3}{*}{ Reference } \\
\hline & & & \multicolumn{3}{|c|}{ No. of Cases } & & & & & & Nursing & & & \\
\hline & & & Total & Male & Female & & & & & & only) & & & \\
\hline 1934 & $\begin{array}{l}\text { Los Angeles } \\
\text { County } \\
\text { Hospital, } \\
\text { Los } \\
\text { Angeles, } \\
\text { U.S.A. }\end{array}$ & $\begin{array}{l}\text { Polio- } \\
\text { myelitis } \\
\text { (concur- } \\
\text { rent } \\
\text { epidemic } \\
\text { of } \\
\text { confirmed } \\
\text { polio- } \\
\text { myelitis } \\
\text { in Los } \\
\text { Angeles) }\end{array}$ & 196 & 28 & 168 & 86 & 131 & 78 & $1 \cdot 6$ & $6 \cdot 6$ & $12 \cdot 0$ & 0 & $\begin{array}{l}\text { Negative } \\
\text { in } 53 \text { out } \\
\text { of } 59\end{array}$ & $\begin{array}{l}\text { Gilliam } \\
\text { (1938) }\end{array}$ \\
\hline 1952 & $\begin{array}{l}\text { The Mid- } \\
\text { dlesex } \\
\text { Hospital, } \\
\text { London, } \\
\text { England }\end{array}$ & $\begin{array}{l}\text { Polio- } \\
\text { myelitis }\end{array}$ & 14 & 0 & 14 & 100 & 14 & 100 & 0 & $0 \cdot 25$ & $2 \cdot 0$ & 0 & $\begin{array}{l}\text { Negative } \\
\text { in } 6 \text { out } \\
\text { of } 6\end{array}$ & $\begin{array}{l}\text { Acheson } \\
\text { (1954) }\end{array}$ \\
\hline 1953 & $\begin{array}{l}\text { The } \\
\text { Whitley } \\
\text { Hospital, } \\
\text { Coventry, } \\
\text { England }\end{array}$ & $\begin{array}{l}\text { Polio- } \\
\text { myelitis }\end{array}$ & 13 & 0 & 13 & 100 & 8 & 62 & - & - & $20 \cdot 0^{*}$ & 0 & $\begin{array}{l}\text { Negative in } \\
9 \text { out of } 9 \\
\text { and } 4 \text { out } \\
\text { of } 5 \\
\text { repeats }\end{array}$ & $\begin{array}{l}\text { Macrae } \\
\text { and } \\
\text { Galpine } \\
\text { (1954) }\end{array}$ \\
\hline 1953 & $\begin{array}{l}\text { Chestnut } \\
\text { Lodge } \\
\text { Hospital, } \\
\text { Washing- } \\
\text { ton, D.C., } \\
\text { U.S.A. }\end{array}$ & $\begin{array}{l}\text { Polio- } \\
\text { myelitis }\end{array}$ & 50 & 2 & 48 & 96 & 47 & 98 & - & - & 42 & 0 & $\begin{array}{l}\text { Negative } \\
\text { in } 25 \\
\text { out of } 25 \\
\text { and } 8 \text { out } \\
\text { of } 8 \\
\text { repeats }\end{array}$ & $\begin{array}{l}\text { Shelokov } \\
\text { et al. } \\
\text { (1957) }\end{array}$ \\
\hline 1955 & $\begin{array}{l}\text { Addington } \\
\text { Hospital, } \\
\text { Durban, } \\
\text { Union of } \\
\text { South } \\
\text { Africa }\end{array}$ & $\begin{array}{l}\text { Polio- } \\
\text { myelitis } \\
\text { (concur- } \\
\text { rent } \\
\text { epidemic } \\
\text { of con- } \\
\text { firmed } \\
\text { polio- } \\
\text { myelitis } \\
\text { in } \\
\text { Durban) }\end{array}$ & 90 & $0^{*}$ & $90^{*}$ & $100^{*}$ & - & 一 & - & - & $20 \cdot 0^{*}$ & 0 & $\begin{array}{l}\text { "Normal in } \\
\text { all but a } \\
\text { very } \\
\text { small } \\
\text { minority" }\end{array}$ & $\begin{array}{l}\text { Alexander } \\
\text { (1956). } \\
\text { Clinical } \\
\text { Meeting } \\
(1955) . \\
\text { Hill } \\
(1955)\end{array}$ \\
\hline 1955 & $\begin{array}{l}\text { The Royal } \\
\text { Free Group } \\
\text { of } \\
\text { Hospitals, } \\
\text { London, } \\
\text { England }\end{array}$ & $\begin{array}{l}\text { Glandular } \\
\text { fever }\end{array}$ & $\left\{\begin{array}{l}292 \\
198\end{array}\right.$ & $\begin{array}{r}27 \\
5\end{array}$ & $\begin{array}{l}265 \\
193\end{array}$ & $\begin{array}{l}90 \\
97\end{array}$ & $\begin{array}{l}149 \\
138\end{array}$ & $\begin{array}{l}56 \\
72\end{array}$ & $\begin{array}{l}2 \cdot 8 \\
0 \cdot 8\end{array}$ & $\begin{array}{l}10.4 \\
11 \cdot 0\end{array}$ & $\begin{array}{l}18 \cdot 5 \\
28 \cdot 0 \dagger\end{array}$ & $\begin{array}{l}0 \\
0\end{array}$ & $\left.\begin{array}{l}\text { Normal } \\
\text { in } 18 \\
\text { out of } \\
18\end{array}\right\}$ & $\begin{array}{l}\text { Crowley } \\
\text { et al. } \\
(1957) . \\
\text { McEvedy } \\
\text { and Beard } \\
(1970)\end{array}$ \\
\hline 1956 & $\begin{array}{l}\text { Freliminary } \\
\text { Training } \\
\text { School of } \\
\text { the Royal } \\
\text { Free Group } \\
\text { of Hospitals, } \\
\text { London, } \\
\text { England }\end{array}$ & $\begin{array}{l}\text { Recur- } \\
\text { rence of } \\
\text { the } 1955 \\
\text { epidemic }\end{array}$ & 7 & 0 & 7 & 100 & 6 & 86 & $0 \ddagger$ & 18 & 20 & 0 & $\begin{array}{l}\text { No } \\
\text { determin- } \\
\text { ations }\end{array}$ & $\begin{array}{l}\text { Geffen } \\
\text { and } \\
\text { Tracy } \\
\text { (1957) }\end{array}$ \\
\hline 1958 & $\begin{array}{l}\text { Queen } \\
\text { Frederica } \\
\text { School } \\
\text { for } \\
\text { Midwives, } \\
\text { Athens, } \\
\text { Greece }\end{array}$ & $\begin{array}{l}\text { Benign } \\
\text { myalgic } \\
\text { encephalo- } \\
\text { myelitis }\end{array}$ & 27 & 0 & 27 & 100 & 26 & 96 & - & - & - & 0 & $\begin{array}{l}\text { Normal } \\
\text { in } 3 \text { out } \\
\text { of } 4\end{array}$ & $\begin{array}{l}\text { Daikos } \\
\text { et al. } \\
\text { (1959) }\end{array}$ \\
\hline
\end{tabular}

* Figures quoted by Acheson (1959, p. 571).

+ Calculated for the four most severely affected institutions within the Royal Free Group of Hospitals.

An eighth case, also a nurse, occurred at the main hospital. The exposed population could be taken either as that of the whole Royal Free Group, or simply as that of the preliminary training school. On the latter view no males were exposed. 
At 6 a.m. on 12 July Case 2 reported sick complaining of headache, malaise, cramps in the legs, pain in the abdomen and back, and dizziness. There was no fever and no abnormality in the central nervous system but she was considered to be a possible case of poliomyelitis when examined at 10 a.m. At much the same time Case 1 complained that she had had a headache since the night before and now felt sick; note was made of a possible reduction of the triceps and supinator jerks on her left side. Both patients were seen again in the course of the afternoon and it was then agreed that they should be "nursed as suspected polio." Various measures were taken in accord with this possibility. The remaining patients in Princess Alice Ward were sent home or put out on the balcony and visiting was forbidden; admissions of children were stopped and operations on children and tonsillectomies on those under 21 were cancelled; children already in the hospital were cared for by nurses with masks; the contacts of the two affected nurses were told to report daily to the sick bay "to have their temperatures taken and for general supervision." Princess Alice Ward was set aside for any further cases that might arise.

In fact, nothing happened from 12 to 29 July, when Case 3 reported sick. This nurse had been ill with vomiting and fatigue in May. As she was pigmented and the pigmentation was increasing she had been admitted for investigation at that time with a presumptive diagnosis of early Addison's disease. All blood tests were negative, as they were during her epidemic admission and during a third admission in 1953. On that occasion, however, it was thought that the diagnosis of Addison's disease had to be accepted on clinical grounds. In 1957 an adrenocorticotrophic hormone (A.C.T.H.) test confirmed the diagnosis; later the same year the patient collapsed and died while in labour; necropsy showed extensive suprarenal hypoplasia. The symptoms with which the patient reported at her epidemic admission on 29 July 1952 were the same as during her earlier and later admissions-nausea and vomiting, plus headache, to which she was always prone. When the results of the serum electrolyte sample taken on 29 July were found to be normal, however, it was felt that the diagnosis of Addisonian crisis could not be retained and on 30 July she was transferred to Princess Alice Ward as the third case of suspected polio.

Case 4 reported sick on 8 August with diarrhoea and neck stiffness. Kernig's sign was positive so she was admitted to Princess Alice Ward; there were no other abnormal findings. The next six cases came, comparatively speaking, in a rush. Case 5 complained of headache and aching in the legs on 10 August, Case 6 of stiff neck and sore throat on the 11th, and Case 7 of headache, pain in the back, and feeling faint on the same day. Then Case 8 reported sick on the 13th with pain in the right leg and headache and Case 9 with an ache in the back and in the left leg on the 15th. None of these cases showed any signs in the central nervous system; all were admitted to Princess Alice Ward, which was now in being as a polio unit.

By this time the number of contacts among the nursing staff who were reporting for daily inspection had risen to over 100. On 19 August this system of observation netted its first patient (Case 11; the sequence is out of order here), who was admitted to the sick bay because her temperature had been slightly raised on the four preceding evenings. The epidemic then petered out, the last three cases occurring in September; on the 5th Case 12 (with sore throat, shivering, and headache), on the 7th Case 13 (with generalized aches and tingling in the arms), and on the 21 st Case 14 (with cramps in the legs).

The striking thing about the presenting symptoms of these cases is their lack of consistency. In some instances it is clear that the symptoms are characteristic of the patient as an individual rather than of a common illness. In particular, Case 3 had symptoms which were surely a reflection of her chronic adrenocortical insufficiency. She was included in the "epi- demic" only because of a negative test for serum electrolyte disorder-a test that was never positive at any time up to her death. Similarly, Case 11 was admitted because she had a tendency to run low-grade evening pyrexias; this tendency was still present when she was declared fit for discharge. Case 8 had diarrhoea. Case 1, on admission, seems to have been a straightforward case of tonsillitis. Hence a whole range of illness seems to have been present among the nurses admitted to Princess Alice Ward over this 10-week period.

\section{Altered Medical Perception of the Community}

The Middlesex is a large hospital. During 1950 the number of times nurses reported sick totalled 1,249; the number of nurses admitted was 151. The period covered by the 1952 epidemic is a fifth of a year, during which time one would expect (at the 1950 rate) 250 nurses to report sick and 30 of them to be sufficiently ill to require admission. This is a large enough flow to provide for an epidemic of 14 cases, if all illnesses not immediately diagnosable as something else were regarded as "query polio." In our view the "epidemic" was an artefact due to an altered medical perception of the community.

The corollary to this view is that the syndrome which characterized the patients after admission was due to: (1) a rising anxiety level on the part of the patients who were under threat of paralysis, and (2) a concentration of medical examination on the central nervous system.

The syndrome was primarily characterized by the subjective phenomenon of "severe muscular pain, affecting the back, limbs, abdomen, and chest" (Acheson, 1954 p. 1044 col. 2.). This type of pain is not currently recognized as a usual way for anxiety to manifest, but there is no reason why such pains should be considered definitely organic. Via the mechanism of overbreathing, anxiety could certainly be responsible for another part of the clinical picture-paraesthesiae and cramps (Acheson, 1954 p. 1045 col. 2: paraesthesiae or tingling a general feature; spasm present in five cases)_and it could well be the underlying factor in the high incidence of difficulty with micturition (Acheson, 1954 p. 1045 col. 1: 8 out of the 14 cases). Moreover, the presence of anxiety as a symptom in its own right, though not mentioned in Acheson's paper, cannot be doubted; there are entries in the notes of 8 of the 14 cases which are directly or indirectly suggestive of a functional element.

So far as the evidence from clinical examination goes, the physical signs that were elicited were few in number and usually indefinite in quality. There is a total lack of groups of physical signs that are mutually consistent and point to a specific neurological (or other organic) dysfunction. Most of the positive clinical findings involve a response by the patient, as, for example, in tests of sensation or motor weakness, or else a large subjective element on the part of the examiner ("all reflexes slightly depressed"). Acheson admits that "the estimation of the degree of paresis and of reflex changes in the affected limbs was extremely difficult in the acute stage." $\mathrm{He}$ adds, "in five cases the deep reflexes in the affected limb were exaggerated; in one case they were normal; and in three cases they were depressed." We believe that these results are better interpreted as a scatter around normality rather than as a shift in any pathological direction.

We think that the 14 patients became a homogeneous clinical group only after admission, and that the symptoms then produced were due to a preoccupation with poliomyelitis on the part of both doctors and patients.

\section{Mechanisms in Hospital Outbreaks}

We now have two mechanisms for the production of epidemics of "benign myalgic encephalomyelitis." In the first 
there is a rapidly propagating hysterical epidemic, which produces many cases in a short period of time; the response of the medical authorities is secondary, and, though it can perhaps influence the further spread of the epidemic and the rate of recovery of those already affected, it is irrelevant to the genesis and establishment of the outbreak. We believe that the Royal Free Hospital epidemic exemplifies this category best; it is difficult to see how the preliminary opinions of the medical staff, which were formed in response to the epidemic, can have influenced its appearance. The outbreak seems to us to have been an uncontaminated example of mass hysteria.

The second mechanism is illustrated by the Middlesex epidemic. On the basis of two patients with suspected poliomyelitis, both of whom it was later conceded had not got the disease, a polio epidemic was declared in being and further cases were expected. Illness was searched for in the community and, unsurprisingly, illness was found. Among those affected it is not unlikely that there was an occasional anxiety state, for this is a common condition and the community was under stress (the threat of polio). There is, however, no evidence that anxiety propagated through the population; there was no mass hysteria. The cases collected probably represented the normal sickness rate for the community, and the fact that they were collected was due to an increase in medical vigilance. It would be wrong to term this an iatrogenic epidemic, for in our view there was no epidemic at all; the basic phenomenon was an altered medical perception of the community.

If these mechanisms are applied to the list of hospital epidemics it seems fair to say that at all institutions except the Middlesex Hospital anxiety must have been self-propagating and mass hysteria the major factor at work, because the attack rates are so high. Possibly the belief of the medical staff that they were dealing with a polio epidemic may have heightened the tension and encouraged this propagation. In the case of the Los Angeles and Durban outbreaks the medical staff were dealing with a polio epidemic in the outside community. In these instances the simplest explanation is surely that a bona fide polio epidemic was the initiating stress for an hysterical response by the nursing community.

But in the presence of a concurrent poliomyelitis epidemic the reaction of the medical staff also has to be taken into account. Two quotes from an account of the Los Angeles epidemic illustrate the two factors at work (Stevens, 1934): "Patients were parked on stretchers and in automobiles in the court awaiting admission. Doctors, nurses, orderlies, maids, ambulance drivers, and all others worked overtime, often for 24 to 48 hours without let-up. Fatigue, loss of sleep, and constant exposure to poliomyelitis in its most infectious stage was common to all."

"All suspects were held 10 days for observation, and known direct contacts released at the end of these periods were required to report back for muscle checks at a specified time, to avoid overlooking mild cases."

So the Los Angeles and other hospital outbreaks associated with poliomyelitis cannot be considered such "pure" examples of mass hysteria as the Royal Free epidemic. An altered medical perception of the community may well have been an additional factor.

\section{Other Outbreaks}

We can now look at the remaining seven epidemics reviewed by Acheson (1959); those that took place in communities as opposed to institutions. Five of the seven fit easily into the conceptual framework we have established (Table II). There was a bona fide poliomyelitis outbreak in each of these communities which was accompanied by an outbreak of benign myalgic encephalomyelitis. In the small communities of Akureyri (Iceland) and Seward (Alaska) the number of benign
TABLE II.-Epidemics of Benign Myalgic Encephalomyelitis Associated with Poliomyelitis Epidemics

\begin{tabular}{|c|c|c|c|}
\hline Place & No. of Cases & Incidence & Reference \\
\hline $\begin{array}{l}\text { Akureyri, Iceland, } 1948 \\
\quad \text { (pop. 6,900) }\end{array}$ & $465^{*}$ & $\begin{array}{l}\text { Maximum incidence } \\
\text { in young adult }\end{array}$ & $\begin{array}{l}\text { Sigurdsson } \\
\text { et al. (1950) }\end{array}$ \\
\hline $\begin{array}{l}\text { Adelaide, Australia, } 1949 \\
\text { (pop. 400,000) }\end{array}$ & c. 800 & $\begin{array}{l}\text { Maximum incidence } \\
\text { in young adults } \\
\text { (no sex incidence } \\
\text { figures given) }\end{array}$ & Pellew (1951) \\
\hline $\begin{array}{l}\text { Copenhagen, Denmark, } \\
1952 \text { (pop. } 1 \text { msllion) }\end{array}$ & $\begin{array}{l}\text { No estimate } \\
\text { given }\end{array}$ & $\begin{array}{l}10 \text { selected cases } \\
\text { reported on: all } \\
\text { female; ages } \\
\text { between } 20 \text { and } 41\end{array}$ & Fog (1953) \\
\hline $\begin{array}{l}\text { New York State, U.S.A., } \\
1950015 \text { million) }\end{array}$ & $\begin{array}{l}\text { No estimate } \\
\text { givent }\end{array}$ & $\begin{array}{l}19 \text { selected cases } \\
\text { reported on: } 15 \\
\text { female: one } \\
\text { patient was age } 9: \\
\text { rest between } 21 \\
\text { and } 45\end{array}$ & $\begin{array}{l}\text { White and } \\
\text { Burtch } \\
\text { (1954) }\end{array}$ \\
\hline $\begin{array}{l}\text { Seward, Alaska, U.S.A., } \\
\quad 1954,3,000) \\
\quad \text { (pop, 3,00) }\end{array}$ & $175^{\star}$ & $\begin{array}{l}\text { "Great excess of } \\
\text { females in the } \\
14-45 \mathrm{age} \\
\text { brackets" }\end{array}$ & $\begin{array}{l}\text { Deisher } \\
(1957)\end{array}$ \\
\hline
\end{tabular}

* Including cases of poliomyelitis.

† Sample was 47 cases of whom 11 were undoubted cases of poliomyelitis and 3 more were probable cases. The cases studied were selected from the remaining 33 , with the addition of two cases obtained in clinical practice.

myalgic encephalomyelitis cases was so high that the anxiety must have been self-multiplying. These seem to us instances of mass hysteria in small communities stressed by the threat of poliomyelitis. In Akureyri none of the polio patients died but the three initial victims "were heavily paralysed, and there seems to be no doubt about the correctness of the diagnosis (of poliomyelitis in these cases)." In Seward there were two deaths from bulbar paralysis.

On the other hand, in cities the size of Adelaide and Copenhagen, and a state the size of New York, there would be at any moment of time enough ill or anxious people to provide a pseudoepidemic of the Middlesex type if a small proportion of them were picked up simultaneously. The tendency of the more anxious to have any symptom checked when polio is prevalent, and the tendency of the doctors to take extra care during a polio outbreak could easily lead to the appearance of an "outbreak" of benign myalgic encephalomyelitis simultaneous with a poliomyelitis outbreak. Pellew (1951) had no doubt that the Adelaide cases represented a genuine epidemic, and White and Burtch (1954) took the same view of the cases in New York State. Fog (1953) was more cautious about the Copenhagen cases, labelling them "neuritis vegetativa (epidemica?)." In these three instances, particularly the last two, an altered medical perception of the community seems as reasonable an explanation of events as a mass hysterical reaction.

Acheson's list contains two further epidemics, one in the small community of Punta Gorda, Florida, U.S.A., and one in a soldiers' barracks in Berlin.

The outbreak at Punta Gorda involved both a hospital and the community the hospital served. It could be argued that it really belongs in the category of hospital outbreaks; the attack rate among the hospital staff was $42 \%$ as against $6.1 \%$ in the community. Moreover, the community attack rate, as we will show, is of dubious validity. Unfortunately, the report by Poskanzer et al. (1957) does not say when the hospital staff cases occurred in relation to the epidemic as a whole. It could be that the community investigation was undertaken only as a result of the hospital outbreak.

The attack rate in Punta Gorda was ascertained by a retrospective house-to-house survey covering 1,041 of the 2,500 inhabitants. Sixty-two individuals qualified as having had the illness as defined by: (1) a definite change in physical and/or emotional state, indicating an onset of illness; (2) illness lasting seven days or more; and (3) presence of headache or neck pain plus any four of the following symptoms: fatigue, aching limb pain, anorexia, nausea, impairment of memory, depression, paraesthaesia (if the interviewee had had headache and neck pain, three additional symptoms sufficed). 
As a result of this survey the attack rate for the epidemic illness was estimated at $6.1 \%$ over the preceding four months.

This type of investigation is difficult to accept at face value in the absence of a control study in an unaffected community. The closest comparison we have been able to find is the study carried out by White et al. (1967) on three communities-one in the U.S.A., one in England, and one in Yugoslavia. The questionary in this investigation asked about 13 complaints or groups of complaints, some specific (rupture, varicose veins) and some subjective (headaches, stomach trouble, backache, nervousness). The proportion of people who had suffered from one of the 12 complaints during the preceding year was between $52 \%$ and $74 \%$. Moreover, when asked if they had suffered "great discomfort" in the previous fortnight the number who said yes varied between $24 \%$ (in the English community) and $44 \%$ (in the Yugoslav community). Given this level of background ill-health one cannot feel that the Punta Gorda attack rate of $6 \%$ proves the presence of an epidemic. The investigation seems to us an example of an altered medical perception of the community, possibly as the result of an hysterical epidemic in the local hospital.

The final epidemic in the series is an outbreak among British soldiers in a barracks in Berlin involving seven cases within eight days. (Sumner, 1956). Here there were abnormal laboratory findings in every case (one abnormal cerebrospinal fluid; abnormal white counts in the remainder) and it is dubious if this epidemic really belongs in the series.

\section{Sporadic Benign Myalgic Encephalomyelitis}

The diagnosis of benign myalgic encephalomyelitis can be fitted to a very fair proportion of the minor illnesses seen in the course of medical practice. At the height of the Royal Free epidemic a very wide range of the patients seen at the hospital appear to have been regarded as candidates for the diagnosis. Geffen (1957-8) quotes the following list of cases where "Royal Free disease" was raised as a possibility:

Two nurses from the Royal Free Hospital

Radiographer

One casualty receptionist

One patient from Royal Free Hospital

One cardiological technician

As he says, "this gives you some idea of the difficulties of differential diagnosis." Indeed it makes it almost impossible to know how to assess reports of sporadic cases.

We would, however, note that how much the diagnosis is used seems to depend on how much contact the practitioner has had with the disease in its epidemic form. Out of 52 cases in the five papers quoted by Acheson (1959) concerning sporadic benign myalgic encephalomyelitis, 49 are reported by physicians who had been previously concerned in a hospital outbreak (Hardtke, 1955; Ramsay and O'Sullivan, 1956; Jelinick, 1956; Ramsay, 1957; Galpine and Brady, 1957).

\section{Nomenclature}

As there seems to be a total lack of objective evidence in support of the view that in cases of benign myalgic encephalomyelitis the brain and spinal cord are the site of an infective, inflammatory disease process, we would suggest that the name be discarded. Even if the view that the symptoms are hysterical is not accepted, it would seem prudent to shorten it to "benign myalgia." Our own inclination is for "myalgia nervosa" on the analogy of "anorexia nervosa." This could serve both for the epidemic illness and for any isolated cases of functional disorder which conform to the same clinical picture.

We are grateful to the Board of Governors and the Medical Committee of the Middlesex Hospital for giving us access to the case notes of the 1952 epidemic and for permission to publish extracts.
Acheson, E. D. (1954). Lancet, 2, 1044.

Acheson, E. D. (1959). American fournal of Medicine, 26, 569.

Alexander, J. S. (1956). South African Medical fournal, 30, 88.

Crowley, N., Nelson, M., and Stovin, S. (1957). Fournal of Hygiene, 55, 102. Daikos, G. K., Garzonis, S., Paleologue, A., Bousvaros, G. A., and Papadoyannakis, N. (1959). Lancet, 1, 693.

Deisher, J. B. (1957). Northwest Medicine, 56, 1451.

Fog, T. (1953). Ugeskrift for Laeger, 115, 1244.

Galpine, J. F., and Brady, C. (1957). Lancet, 1, 757.

Geffen, D. (1957-8). Public Health (London), 71, 13.

Geffen, D., and Tracy, S. M. (1957). British Medical fournal, 2, 904.

Gilliam, A. G. (1938). Public Health Bulletin, No. 240.

Hardtke, E. F. (1955). Fournal of the Indiana State Medical Association, 48, 245.

Hill, R. C. J. (1955). South African Medical fournal, 29, 344.

Hill, R. C. J. (1955). South African
Jelinek, J. E. (1956). Lancet, 2, 494.

Lancet, 1956. 1, 789.

Leake, J. P., Cedar, E. T., Dearing, W. P., Gilliam, A. G., and Chope, H. D. (1934). American fournal of Public Health and the Nation's Health, 24, 1204.

Macrae, A. D., and Galpine, J. F. (1954). Lancet, 2, 350

McEvedy, C. P., and Beard, A. W. (1970). British Medical fournal, 1, 7.

Pellew, R. A. A. (1951). Medical fournal of Australia, 1, 944.

Poskanzer, D. C., et al. (1957). New England fournal of Medicine, 257, 356.

Ramsay, A. M. (1957). Lancet, 2, 1196.

Shelokov, A., Habel, K., Verder, E., and Welsh, W. (1957). New England fournal of Medicine, 257, 345 .

Sigurdsson, B., Sigurjónsson, J., Sigurdsson, J. H., Thorkelsson, J., and Grdsson, B., Sigurjónsson, J., Sigurdsson, J. H., Thorkelsson, J.,
Gudmundsson, K. R. (1950). American fournal of Hygiene, 52, 22.

Stevens, G. M. (1934). American fournal of Public Health and the Nation's Health, 24, 1213.

Sumner, D. W. (1956). Lancet, 1, 764.

White, D. N., and Burtch, R. B. (1954). Neurology (Minneapolis), 4, 506.

White, et al. (1967). New England fournal of Medicine, 277, 516. 